\title{
CIAM Network Visualisation - Detecting Ideological Ruptures in the CIAM Discourse
}

Bjažić Klarin, Tamara; Bojić, Nikola

Source / Izvornik: Modern and Contemporary Artists' Networks. An Inquiry into Digital History of Art and Architecture, 2018, 64 - 82

Book chapter / Poglavlje u knjizi

Publication status / Verzija rada: Published version / Objavljena verzija rada (izdavačev PDF)

https://doi.org/10.31664/9789537875596.04

Permanent link / Trajna poveznica: https://urn.nsk.hr/urn:nbn:hr:254:143161

Rights / Prava: In copyright/Zaštićeno autorskim pravom.

Download date / Datum preuzimanja: 2023-04-26

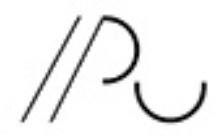

INSITIUT ZA POVIJEST UMJETNOSI
Repository / Repozitorij:

PODEST - Institute of Art History Repository

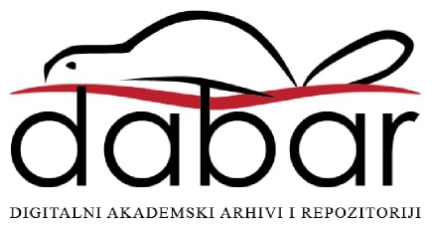




\section{CIAM Network Visualisation -}

Detecting Ideological Ruptures in the CIAM Discourse

DOI: https://doi.org/10.31664/9789537875596.04

Tamara Bjažić Klarin

Nikola Bojić
Active between 1928 and 1959, the International Congress of Modern Architecture (CIAM - Congrès Internationaux d'Architecture Moderne) was a leading forum on modern architecture and urbanism, playing a key role in their affirmation and dissemination both before and after the Second World War. Over the course of ten thematically focused congresses, several executive committee and counci sessions, and numerous meetings, CIAM evolved as an extensive international network of architects. The logic of its organ isation combined two opposing models, which were typical for architecture and fine arts of the 19th and 20th century - a model of artistic/architectural groups that were founded on ideologically and for mally close standpoints, and a model of professional association. Whereas the first model of organisation is often based on informal, non-hierarchical relations, the second model is often characterised by a centralised decision-making process. As we argue in this paper, the frictions of these essentially different organisational concepts, are one of the main cause of discursive ruptures that lie behind the turbulent evolution and finally the end of CIAM. Although gathered around a com mon idea of modern architecture, CIAM members did not have the possibility of independent creative action and expression of personal stances, nor any rea opportunity to participate in the overall decision-making. Aspiring to overcome academism and secure a predominan position of new architecture within an official public discourse, CIAM followed a strictly defined hierarchical structure, similar to the organisation of professiona associations.

The second, not less significant reason of discursive ruptures were the differences in the understanding of architectur social role and the associated political

\section{iAM's members. ${ }^{104}$ From the} political spectrum, the role of architec ture surpassed the technical and formal aspects of the profession and delved into the domain of social and political action. This view was opposed to the idea of architecture as a technical discipline with no predefined ideological position, which can easily align with different politica standpoints. ${ }^{105}$ Ideological conflicts were also the conflicts between generation that were advocating different models of CIAM's organisation and action. Therefore, there was the "revolutionary youth" yearning for democracy on one side, and older generation prone to opportunism on the other. The latter primarily refers to Le Corbusier, CIAM's secretary Sigfried Giedion and Walter Gropius, who were in favour of an autocratic type of management of CIAM.

Despite different standpoints and frequent conflicts, CIAM was perceived as a monolithic organisation. Along with Le Corbusier, its co-founder and ideologist, CIAM became the synonym of modern architecture rooted in the canonical concepts of "a functional city" and "five points of modern architecture". As pointed out by Kenneth Frampton, the image of CIAM began to be perceived differently because of the research and publication

104 They belonged to different political orientations - radical left, centre and right. While the Nazis were the opponents of Neues Bauen, which was deemed a communist and Jewish creation, the Italian group was in its favour.

105 The positions assumed significantly affected the approach to planning, building and design. The subject of controversy was the level of typifying, standardisa-

tion and prefabrication. Whilst the first group saw these as tools, the other understood them as a necessity. 
by Ulrich Conrads and Eric Mumford, the author of the first comprehensive overview of CIAM's work, The CIAM Discourse on Urbanism, 1928-1960, which provided an insight into all its congresses, working bodies and participants. ${ }^{106}$ This book provides an insight into the role of each member of CIAM in the tailoring of its history and thus - directly or indirectly - in the tailoring of the history of architecture and urban planning of the 20th century. In order to get a comprehensive view of the pre-war history of CIAM, it is equally important to look at the research undertaken within the project Atlas of the Functional City: CIAM 4 and Comparative Urban Analysis and to explore the research on Cornelis van Eesteren carried out by Kees Somer, while for the history of Team 10, Alison Smithson's Team 10 Meetings 1953-1984 and the study of a group of authors Team 10: In Search of a Utopia of the Present 1953-1981 were crucial. ${ }^{107}$ Based on the abovementioned sources, as well as on the research of archival materials from the Institut für Geschichte und Theorie der Architektur (gta) ETH in Zürich, the Fondation Le Corbusier in Paris and Het Nieuwe

106 Foreword by Kenneth Frampton in: Eric Mumford: The CIAM discourse on urbanism, 1928-1960 (Cambridge, Mass.: MIT Press, 2000).

107 Kees Somer: The Functional City. The CIAM and Cornelis van Eesteren, 1928-1960 (Rotterdam: nai010 publishers, 2007);

Evelin van Es et al., eds., Atlas of Functional City. CIAM 4 and Comparative Urban Analysis (Zürich \& Bussum: gta

Verlag \& Uitgeverij THOTH, 2014); Alison Smithson, ed., Team 10 Meetings 1953-1984 (Delft: Delft University of Technology, Faculty of Architecture, 1991); Max Risselada \& Dirk van den Heuvel, eds., Team 10: In Search of a Utopia of the Present 1953-1981 (Rotterdam: nai010 publishers, 2006).

Fig. 1.

Visualisation of the CIAM network differentiates participation on the pre-war (blue) and post-war (pink) congresses, pointing to the clear cut in the CIAM's history, as well as a number of omnipresent (overlapped) figures in the centre of visualisation.
CIAM participants - CIAM events / pre-war links 
Instituut in Rotterdam, this paper will for the first time show and analyse CIAM as a social network. The aim of this approach is to trace formation and transformation of left tendencies within the overall network and detect discursive ruptures which they directly or indirectly caused.

This research was carried out using digital tools for network analysis and data visualisation developed within ART NET project. ${ }^{108}$ The network is visualised in a circular form, defined by the events that chronologically (clockwise) concatenate on its perimeter. Each of these events is linked with a line to the persons who participated in it. The participants of a single event remain outside the circle's perimeter, whereas those who participated in two or more events are located within the circle. Based on a calculation of the measure of centrality, specific positions of persons within the circle point to their greater contribution to CIAM's discourse (Fig. 1). Furthermore, the circular network's topography enables mapping of social encounters in time and space and identification of certain groups with potentially firmer inner cohesion ("social clique"). ${ }^{109}$ A more precise description

108 The data on 331 architects, members of CIAM, 22 corresponding national groups and 32 events - CIAM congresses and related executive committee and council meet-

ings was processed. The materials from the mentioned archives were used as a source of data on congresses, meetings and their participants, while the complete list of CIAM events brought by Eric Mumford was used as a reference point. (Mumford, The CIAM, 275-276).

109 The simultaneous and multiple type of space and time overview, as well as social events linked to it, which are the backbone of the proposed visualisation, theoretically relies on the concept of time geography, and more specifically on of relations between the persons within clique requires processing additional archive material (the content of mutual correspondence, different types of cooperation, mentorships, friendships etc.), which goes beyond a mere presence at a same event. The latter is key to the overview and analysis of ruptures, which are in the focus of this paper.

\section{MODUS OPERANDI OF}

CIAM AND ITS RUPTURES

Gathered in La Sarraz in 1928 as a group of individuals with a mission to promote modern architecture, CIAM very soon articulated an atypical organisational structure that serviced the main working platform - so-called working congresses. ${ }^{110}$ Set up according to the bottom-up model, CIAM national groups were the basis of this structure. Its members participated in the work of the CIAM's general assembly, which was held during each congress. ${ }^{111}$ The groups produced congress material used to articulate CIAM's strategic documents - recommendations

the work of Swedish geographer Torsten Hägerstrand (1916-2004). See: Torsten Hägerstrand, "What about people in regional science?",Papers of the Regional Science Association no. 1 (1970): 6-21.

110 Although established as a biannual event, the congresses were held in 1928 (CIAM 1), 1929 (CIAM 2), 1930 (CIAM 3), 1933 (CIAM 4), 1937 (CIAM 5), 1947 (CIAM 6), 1949 (CIAM 7), 1951 (CIAM 8), 1953 (CIAM 9) and 1956 (CIAM 10).

111 The assembly provided personal contacts among CIAM members, enabled voting on declarations, and dissemination of CIAM's objectives (Commission II. Reorganisation, in: CIAM 5 documents. Bridgwater, 1947 (Zürich: gta ETH, 42-AR-1-9) for further development of urban planning and habitat of the $20^{\text {th }}$ century. The themes (tasks) became more complex over time. Prior to the Second World War these involved minimum dwelling (CIAM 2) and rational planning of residential areas (CIAM 3), functional cities (CIAM 4) and regional planning, i.e. "logis et loisir" (CIAM 5). After the Second World War, the congresses entailed several architectura and urban planning issues focusing on habitat (CIAM 7, CIAM 9 and CIAM 10) and the city "core" (CIAM 8) discussed through recent projects.

Nominally, until the Second World War the main body of CIAM organisation was the (Executive) Committee for the Solution of the Problems of Modern Architecture (CIRPAC - Comité international pour la réalisation des problèmes d'architecture contemporaine). CIRPAC directed and organised the work of CIAM. It was com posed of two representatives - delegate - from each national group who controlled the flow of information from CIRPAC to the national base and who introduced new national members to CIAM. This type of organisational structure entirely relied on personal contacts, friendships and connections. Unlike international professiona organisations, whose members are nom inated by national professional entities, this type of organisational structure is another particularity of CIAM, and the argument in favour of approaching it in terms of a social network.

Regardless of the official organisationa structure, decisions were taken from 193 onward within the circle - Le Corbusier, Sigfried Giedion and Walter Gropius, who were later joined by José Luis Sert. The central position of core actors within $\mathrm{Cl}$ AM's network confirms their influence (Fig. 1). At last their position was formalised during the first post-war congress by their appointment to the newly founded execu- ive body - Council, while CIRPAC lost its portance. ${ }^{112}$ National groups continue to have their delegates, but they no longe participated in the work of CIAM's executive body. ${ }^{113}$ Taking into consideration the desire for democratisation of CIAM the establishment of the Council, whos task was "to meet more frequently for the direction of CIAM and the representation of CIAM aims", produced quite the contrary effect. ${ }^{114}$ The position of nationa groups remained the same (each countr was allowed to be represented by severa groups, and so France had groups Ascora and Bâtir, and the Netherlands Opbouw and De8), while the impact of the delegates on CIAM's policy and programme was significantly reduced and extremely localised. ${ }^{115}$ Furthermore, as the visualis ation shows (Fig. 1), there is a clear cut between CIAM's network prior and post war, which is confirmed by a relatively low number of names appearing in both periods. The group with a continuity of presence, having thus the biggest impact

112 Rudolf Steiger and Cornelius van Eesteren were also the members of the Council. In the light of the Allies victory, they were joined by the less prominent representatives of Hungary and Czechoslovakia.

113 The setting up of the council was the result of reorganisation, which was the topic of the first post-war congress in Bridgwater in 1947. A separate commission was in charge of discussed congress topics. This practice was already established before the Second World War.

114 Commission II. Reorganisation, in: CIAM 5 documents, 10.

115 "The delegates or vice-delegates shall be accepted as the intermediaries for ensuring that the work of the local groups is in conformity with the aims of CIAM." Commission II. Reorganisation, in: CIAM 5 documents, 9 . 
on CIAM, is the mentioned clique that is located in the central position within the network's topography.

Notwithstanding the significance of Le Corbusier's role in the history of architecture or his unique talent, from the very beginning, CIAM existed in Le Corbusier's shadow. The uncompromising imposition of his own vision of architecture and urbanism, his professionally dubious actions and political views, elitism, egocentrism and desire for power placed him at the very centre of CIAM's network. At the same time, his central position was also an incentive to develop a different vision of CIAM's organisation and to rethink the social role of architecture. Le Corbusier's most fervent critics and opponents were recruited from the circle of his collaborators. Therefore, Le Corbusier can be seen as the centre of CIAM's network but also the main cause of the abovementioned ruptures.

Le Corbusier was continuously opposed by the cliques of left-wing architects, the advocators of the idea of an egalitarian democratic society, which they wished to introduce into CIAM organisation. The composition, dynamics and mode of action of these cliques changed in sync with the changes of social and political circumstances. Given the historical context, the roles of cliques moved from founders / leaders (1928-30) and opposition / rebels (1932-37) to reformers (1953-59). ${ }^{116}$ They all shared a common understanding of architecture as a tool for developing a more equitable society and advocated

116 The first and the second clique was focused on the existential minimum (slums clearance and social housing) while the third clique delved into a stimulating living environment under the conditions of constant growth and mass housing production in a welfare state.

Fig. 2

Visualisation of the CIAM network shows distribution of the members of the three left-oriented cliques (founders, rebels, reformers) and the CIAM leadership along with the participation of each person in different congresses (grey lines).

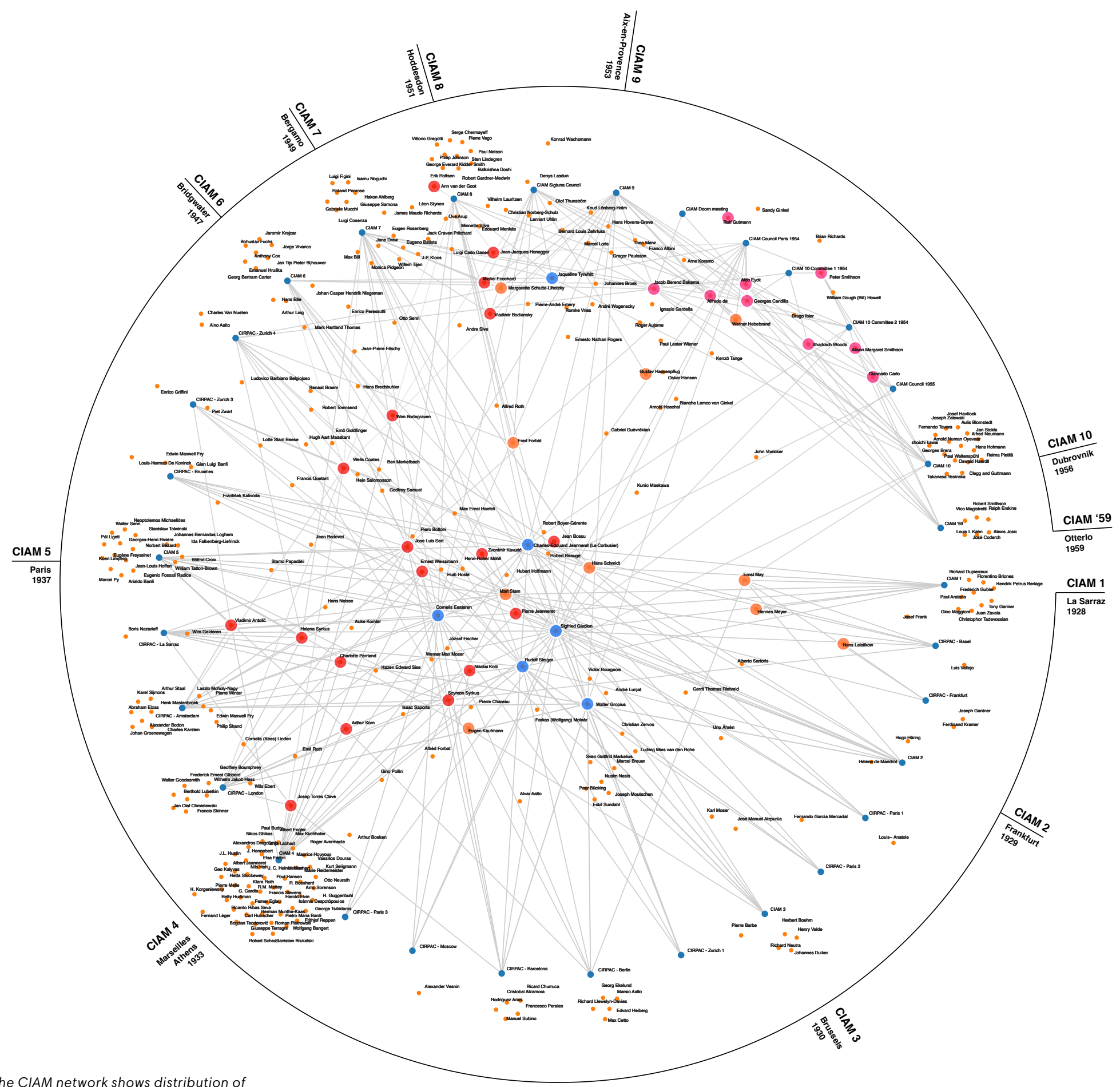

CIAM participants - CIAM events 
cepts. The analysis of the visualisation of the CIAM's network helps to locate the ruptures caused by the formation of the mentioned cliques - to determine a place and time of their beginning and to identify the mediators - persons who provide their continuity. The first one took place between the CIAM's Second Congress in Frankfurt in 1929 and "Special Congress" in Berlin in 1931. ${ }^{119}$ The second rupture occurred during the Fourth Congress in Athens in 1933, while the third one came to be exactly two decades later, on the occasion of the Ninth Congress in Aixen-Provence in 1953.

May, Schmidt, Stam and their like-minded associates briefly led CIAM, from its founding congress in La Sarraz in 1928, until the preparation of CIAM 3 when all participants were acquainted with the achievement of the Weimar Republic new workers' housing estates and social standard facilities. Only after this group left to the USSR in 1930 and formed the so called May's Brigade, did Le Corbusier come to power. ${ }^{120}$

After this first wave of exodus of German architects to the USSR, the second exodus occurred in the mid-1930s when the Nazis came into power. Many left-wing and Jewish architects, including those who returned from the USSR disappointed with Stalin's politics, left for the Great Britain and the USA. As a consequence, the engagement of May's Brigade members in

119 Mumford, The CIAM, 59.

120 Hannes Meyer also participated in CIAM 1. Hans Schmidt left for Moscow in 1930 to fill the position of advisor to the People's Commissariat of Heavy Industry. Along with his international reputation, acquired in the 1920 s thanks to publicist and theoretical work, Le Corbusier also realised his first public building at that time. 21 Arthur Korn was not the Brigade member, but he shared its fascination with USSR

\section{"WE HAD ANOTHER VERSION} OF THE CHARTER"122

The "rebels" were doomed to fail because of the lack of their authority. They were mostly young architects, born in the be ginning of the $20^{\text {th }}$ century, who were un able to achieve their potential amidst the omnipresent economic crisis. An exception to this was José Luis Sert, a member of GATCPAC, involved in the construction of a respectable number of public build ings during the Second Spanish Republic Furthermore, together with Weissmann and Sert, the core of the "rebels" involved Josep Torres Clavé, Charlotte Perriand, Pierre Jeanneret (Le Corbusier's partner) and Jean Bossu. All of them, except Tor res Clavé, worked in Le Corbusier's studio where they were introduced to Sigfried Giedion and Mart Stam. The studio was a meeting point of CIAM's senior leadership and members who would stop in Paris on their journeys through Europe. Le Corbusier rarely involved his collabora tors in the discussions about CIAM and it organisation. For example, it was Weiss mann who proposed Sert's participation at Frankfurt congress to Giedion, not Le Corbusier. Moreover, in a letter sent to Giedion, Weissmann complained that Le Corbusier did not share any information with his collaborators. For him, CIAM was a circle of elite architects, rather than a polygon for the affirmation of young generations. ${ }^{123}$

122 Ernest Weissmann, "We had another version of the charter", Arhitektura no. 189-195 (1984-1985): 32-37.

123 This is explicitly seen in the invitations sent for CIAM 1 , one of these being addressed to Weissmann's professor Hugo Ehrlich. Weissmann attended CIAM 2

occasion for the open confrontation ciaM leadership was the cancellation of the Fourth Congress in Moscow. ${ }^{24}$ The young maintained close connection with the USSR and were fully acquainted with the work of Russian and German urban planners on the linear city concept (Sotsgorod)..$^{25}$ Following a two-yea break, Weissmann once again took part in the CIAM during the CIRPAC meeting in Barcelona in 1932. At that very moment, he was aware of the significant ideological changes that occurred within CIAM. The departure of German architects and the inclusion of the Italian Gruppo Sette, supporters of Mus solini's fascist regime, made CIAM leadership take an apolitical stance. Detached from the real-life, official CIAM leadership tended to deal with the burning issues of the $20^{\text {th }}$ century (primarily housing crises) without any real involvement in their social and political causes. The apolitical and socially inactive stance provoked a second wave of resistance. As a central figure of this resistance, Weissmann responded promptly by gathering all like-minded members of CIAM national groups and organising a public de bate at the upcoming CIAM 4. Due to many connections and activities they had, both Weissmann and Sert are centrally located in

Giedion, November 19, 1930 (Zürich: gta ETH, 42-K-1930-W).

124 Giedion and Van Eesteren's visit to Moscow preceded the cancellation of the congress. The congress was postponed in order to prepare a thorough overview of new soviet cities with the aim of comparing them to the cities of the capitalist West. The visit was possible, since the very same year L'Architecture d'Aujourd'hui organised an excursion of French architects to the USSR Anon., "Architecture et urbanisme en U.R.S.S.", L'Architecture d'Aujourd'hui no. 8 (1932): 49-96.

125 They planned a trip to the USSR in together with Sert and Kunio Maekawa. Ernest Weissmann, Letter to Sigfried 
the pre-war "hemisphere" of CIAM's activity, as the opponents to the leading figures (Fig. 2, Fig. 3).

In the summer of 1933 in Athens, rebellious Croatian, Spanish and French architects were joined by their English, Polish and Dutch like-minded peers (Wells Coates, Szymon Syrkus, Helena Syrkus and Wim van Bodegraven). Dissatisfied with the intention to limit urban planning merely to technical aspects, the group suggested an alternative version of the Athens Charter, in order to bridge a gap between the apolitical 'inherent' professionalism of architects, urban planners and civil-engineers and their real social-political functions in societies with different economic systems, at different levels of technology and industrialisation. ${ }^{126}$

A prerequisite for realising an alternative charter was the necessary change in the modality of land use and appropriation of the means of production. In order to achieve it, Weissmann proposed a radical political act - abolition of private ownership on behalf of the common good and the "distribution of urban elements irrespective of private interests". ${ }^{27}$

Quite expectedly, the requests of young architects were unacceptable to the pragmatic leadership of CIAM. To Le Corbusier, architecture was the means to ensure status quo, and to prevent a possible revolution. At the first CIRPAC meeting held after CIAM 4 in London in 1934, Corbusier and Giedion managed to restrain the revolutionary

126 Weissmann, "We had another version of the charter".

127 Radna grupa Zagreb, The first draft of the alternative version of the Athens Charter, August 10, 1933 (Zagreb: Hrvatska akademija znanosti i umjetnosti, Hrvatski muzej arhitekture, Vladimir Antolić Personal Archive) was designated as a par excellence professional association, providing exclusively technical solutions for the problems of the modern city. Their implementation was politicians' responsibility. Afterwards, "rebels" briefly retreated into a "grey zone" but remained in contact and active, both within the British MARS Group and in the French CIAM Group. ${ }^{129}$ Aware of this shift, Gropius warned Giedion of the "communist" activity of certain CIAM members and urged him to decisively oppose to the intentions to push CIAM in a different direction. ${ }^{130}$

From 1935 on, Paris was the centre of $\mathrm{Cl}$ AM's left-wing tendencies, which reached peak during the time of the Popular Front government. Due to the rise of Nazism and the Spanish Civil War, the French group of CIAM took over the organisation of CIAM 5 in Paris in 1937.131 The French Group had already accrued an extremely complex and colourful history, both because of the conflict between Le Corbusier and leftist architect André Lurçat and because of a relatively large number of fluctuating foreign members such as Paul Nelson, now

128 Weissmann, Sert, Szymon Syrkus, Coates and Torres Clave attended the meeting.

129 The "rebels" followed the established working agenda. Limited by funding they gathered right before the CIRPAC meetings.

130 Walter Gropius, Letter to Sigfried Giedion, February 14, 1935 (Berlin: Bauhaus Archive, Gropius-Nachlass Collection, 12/505).

131 It was initially planned to continue to work on the issue of the functional city discussing particular projects and then to proceed with regional planning. In January, it was then decided to go for a more populist theme, interesting to a broader public. The Congress was held at the time of the Paris International Exhibition. émigré José Luis Sert, and Weissmann. From 1935, the latter one continued to be the main mediator of the left-wing opposition. At CIRPAC meeting held in the same year in Amsterdam, the group was joined by Mart Stam who had just returned from the USSR. His engagement united the founders (May's brigades) and the new generation of the CIAM left. Interestingly enough, Weissmann's political role during the pre-wa period, was three decades later assumed by Jaap Bakema, Stam's graduate student, and a central figure of Team 10 (Fig. 3).

The young architects began a new phase of their work with an exhibition in the Cahier d'Arts Gallery. ${ }^{132}$ Its organisers, Weissmann, Charlotte Perriand and Robert Poursain, presented the work of national groups (Spanish GATEPAC, Polish PRAESENS and U, and Yugoslavian Radna grupa Zagreb), an invisible base of CIAM which carried out huge and complex tasks for the needs of the congresses, but had no right to participate in the development of its programme nor in the overall organisation's decision-making. The goal of the exhibition was to point to the need for reorganisation of CIAM to reach a greater degree of participation of al its members in the work of the congress. As expected, the exhibition was not well received by Le Corbusier with whom Per riand, Pierre Jeanneret, Jean Bossu and Weissmann terminated collaboration following heated tensions during the work on the Pavillon des Temps Nouveaux. Moreover, as the president of the commission in charge of the evaluation of Le Corbusier's presentation on the theoretical aspects of housing and leisure at CIAM 5, Weissmann criticised and confronted the "cher maître" on behalf of his group. ${ }^{133} \mathrm{He}$ used

132 The exhibition was held from 12 February until 9 March, 1935. a propose a new approach to the topic - a neighbourhood unit as the main urban element, with new housing typologies that facilitate participatio and social interactions. This proposal an ticipated some of the themes that late marked the discourse of Team 10

And while Weissmann was summing up the stances of the young generation and distancing himself from CIAM by temporarily renouncing his active engagement, on of his closest associates, José Luis Sert moved from the camp of the rebellions to the "core" of the organisation durin CIAM 5 (Fig. 3). The upcoming War and emigration of CIAM leadership to the USA opened the political arena within CIAM to the next generation of architects, in cluding the future members of Team 10.134

\section{GRADUAL DYING AWAY}

The second generation of rebels, born in the 1900s, suffered the greatest burden of the Second World War. Their personal participation in CIAM events dropped significantly after the War (Fig. 1). Within the network, rebels' visibility is reduced among other things also due to the mentioned reorganisation - foundation of Council and reduction of CIPRAC authority. Those who remained in CIAM joined the unaltered composition of leaders - L Corbusier, Sigfried Giedion and Walter Gropius. José Luis Sert was an elected president, while Helena Syrkus became vice-president. The War marked a great cut, after which the work of the entire

Vladimir Antolić, Marcel Breuer, Eugen Kaufmann, Artur Korn, Lotte Stam-Besse, Mart Stam and Polyvios Michaelides.

134 Weissmann renewed his activities in the USA. He was in charge of the Yugoslav pavilion at the New York World Exhibition. Bjažić Klarin, Ernest Weissmann, 2015). 
organisation had to begin from scratch the Unité d'habitation in Marseillses. ${ }^{136}$ (Fig. 1). The new beginning was not fol- The similarities between pre-war and lowed by enthusiasm and new themes post-war left, rebels and reformers, are and approaches. Instead of dealing with urgent social needs, such as post-war reconstruction and housing crisis, CIAM leadership continued to deal with the issues relevant to architectural profession, specifically, with the concept of synthesis in architecture. At that very moment, the huge post-war construction projects such as rebuilding Le Havre, Rotterdam and Warsaw had already started.

The new generation of left-wing architects born in the 1910s and 1920s took part in CIAM already in the 1940s. Jaap Bakema attended the first post-war congress in Bridgwater, CIAM 6 in 1947, and Georges Candilis the next one, CIAM 7 in Bergamo, in 1949.135 Both of them took part in anti-fascist resistance during the War and openly sympathized with the communist ideas. Thanks to the post-war welfare state, unlike their predecessors, they had a unique opportunity to take part in the construction of welfare facilities and housing for large numbers. Jaap Bakema and Georges Candilis boasted their first large public projects, international recognition and credibility already in the early 1950s. They also partially owed it to their successful business partnerships- Bakema to Johannes van der Broek, an established architect of the older generation, and Candilis to Le Corbusier's ASCORAL and later ATBAT-Afrique, whose members were Shadrach Woods and Vladimir Bodiansky. Together with Weissmann, Bodiansky was one of the consultants on Le Corbusier's design of the United Nations headquarters in New York while Candilis was architect in charge of the construction of

135 Aldo van Eyck also participated in the work of CIAM from the mid-1940's (Eric Mumford, The CIAM, 172).

godina / CIAM Networking - International

Croatian architects in the 1950s", Život umjetnosti no. 99 (2016), 40-57.
Already during CIAM 7, the reformers started a discussion along the same line of their predecessors. ${ }^{139}$ They acknowledged the lack of free distribution of land as the major issue of urban planning. Candilis, who attended discussions at CIAM 4 on the social assignment and role of "urbanists", proposed the setting up of a special commission that would study "various possibilities of land mobilisation".140 The request by Ernesto Nathan Rogers followed the same line of thought - he advocated the concept of humanist urbanism achieved by "communisation du sol" as the official CIAM's policy. ${ }^{141}$ Expectedly, Le Corbusier rejected all these propos als. He strongly believed that legislators rather than architects, were obliged to provide conditions for the implementation of plans. ${ }^{142}$ In Bergamo, a discussion on the artistic aspect of architecture too place and Rogers reiterated the stances of the pre-war "left". He argued that architecture must act economically, while the artistic expression should remain

139 Schmidt underscored the importance of current social and material circumstances in the opposition to the unification of life in favour of "free development of human needs/volition". 7 CIAM Bergamo 1949. Document (Zürich: gta ETH, 42-JT-4-143).

140 At the time of CIAM 4, Candilis studied architecture at the Polytechnic in Athens. A special commission discussed the legislative aspects of land disposal at CIAM 9. Not coincidentally, Drago Ibler was appointed member of this commission. Les documents de Sigtuna 1952 (Zürich: gta ETH, 42-AR-X-4), 15; Rapports des commissions. Publication interdite, in: CIAM 9. Aix-en-Provence, 19-26 July, 1953 (Zürich: gta ETH), 27-28.

141 The term is "communisation". Compterendu de la séance plénière de la Ière commission, in: 7 CIAM, 141 artistic field. ${ }^{143}$ The same was perceived by Marcel Lods who considered any discussion on the architectural form academism, and thus a complete failure. Lods focused on the pressing issues such as distribution of land and prefabricated housing. ${ }^{144}$ This discussion was probably one of the reasons for abandoning habitat as the theme of the next congress in Hoddesdon in 1951. At CIAM 8, the theme was "the heart of the city". 145 The thematic change, however, did not stop polemica tones. The group of young architects argued for the necessity of reorganisation of CIAM and its leadership. After the three post-war congresses, it was obvious tha CIAM lost its direction and the difference between the leadership, at that moment based in the United States, and the new generation in Europe were growing. The new generation was encouraged by the temporary appointment of Dane Vilhelm Lauritzen, Brit William Howell and George Candilis as Council members. ${ }^{146}$ Unlike the

\section{CIAM, 159}

144 Lods co-authored a housing estate Cité de la Muette in Drancy constructed by using prefabrication in early 1930's (7 CIAM, 161)

145 The planned issue was also changed after CIAM 4. Instead of regional planning and application of the Athens charter, it was changed to Logis et loisirs. HABITAT goes beyond the issue of housing as a physical shelter. It unified the "environnement urbanistique", "logis", "hommes" and "environnement immediat"- that is, apartment or house and its surroundings taking in consideration the social and psychical needs of a man.

146 Laurizten represented the Scandinavian countries while Howell and Candilis acted as the representatives of the "young architects". Council Meeting, in: CIAM 8. 1951 Report of Hoddesdon Conference (Zürich: ETH gta, JT-6-23). 
previous generation of rebels, positioned in the very centre of visualisation along with the core leadership, this threesome appears at its very rim. Along with Team 10 members, the threesome contributed to the formation of a dynamic clique that for the first time broke the perimeter of visualisation, implicating further turbulences and the final fall of CIAM (Fig. 3).

At the congress in Hoddesdon, Weissmann re-established contacts with CIAM. Immediately after his appointment to the position of director of the Housing and Town and Country Planning Section (Department of Social Affairs, The United Nations, New York), he offered to CIAM a cooperation on the issues of habitat and urban planning - through a newly established CIAM United Nations' group. Sert refused the proposal, claiming that this was contrary to the UN rules. ${ }^{147}$ The collaboration was established through a working group appointed to develop a UN technical assistance programme. Gathering Jean Jacques Honegger, Vladimir Bodiansky, Georges Candilis, Michel Ecochard and Weissmann, the group established another direct linkage between the pre- and post-war leftist tendencies and once again, among its members were Le Corbusier's collaborators (Fig. 3). Before the Second World War, Weissmann collaborated with Charlotte Perriand, Pierre Jeanneret and Jean Bossu, and on this very occasion, he was after members of ATBAT-Afrique - Bodiansky and Candilis. They were chosen for their

147 As Weissmann was not able to attend the congress, the UN representative was Ann van der Goot, a Belgian employed at the United Nations Town and Country Planning Section. "Main points of speech of A. van der Goot. Representative of United States", in: CIAM 8, 101-102; Rosemary Wakeman, "Rethinking postwar planning history", Planning Perspectives, no. 2 (2014): 153-163). experience in the underdeveloped countries. ${ }^{148}$ The working group in charge of the technical assistance programme became active in November 1952 in-between two events decisive for CIAM - a CIAM council and delegates meeting in Sigtuna in June 1952 and a breakthrough CIAM 9 in Aixen-Provence in July 1953. In Sigtuna, the reformers met for the first time without the presence of Le Corbusier, Sigfried Giedion, Walter Gropius and Jose Luis Sert, discussing "what was to become of CIAM", ${ }^{149}$ while in Aix-en-Provence Team 10 gathered for the first time on the roof of the Unité.

Known as the congress of the youth, CIAM 9 marked the beginning of leadership "hand over". ${ }^{150}$ Candilis emphasised the similarities between CIAM 4 and CIAM 9. Both congresses aimed to establish a charter (of functional city and habitat) and brought about the association of the leftists, who were critical of CIAM's undemocratic de-

148 ATBAT-Afrique was the African branch of ATBAT, Atelier des bâtisseurs, founded in 1947 by Le Corbusier, Vladimir Bodiansky, André Wogenscky and Marcel Py, with Jacques Lefèbvre as commercial manager. This so-called atelier was conceived as a research centre, where architects, engineers and technicians could work in an interdisciplinary fashion. Along with Candilis, Shadrach Woods was the second member of Team 10 active in Le Corbusier's atelier. (Projet d'assistance techniques des Nations Unies (Zürich: gta ETH, 42JT-12-317/353; http://www.team10online.org/ team10/candilis/index.html)

149 Smithson, Team 10, 18.

150 CIAM 9 gathered around 3000 participants, including students. Handover was agreed during the meeting between Le Corbusier and Giedion in July 1955 in Paris. (Aspects of Program for CIAM $X$ at Dubrovnik to be given final form at Padova, Aug. 2/3. 1956. (Zurich: gta ETH, 42-AR-14-130/131) cision-making and outdated approaches to the problems of the city. This time, the political issues were not in question. The young architects gathered around Team 10 were fed up with high modernism, architecture based on "five points" and the functional city. They were eager to start their own pursuit for new architectural and urban planning models that would correspond to the new urban programmes and new socia needs. ${ }^{151}$ As Alison Smithson concluded, the interwar battle "for "éspase, soleils, verdure" was over and they were eager to create the architecture of "hope, freedom, identity, change" and "invent architectural language appropriate to the evolving present." 152 Already in Aix-en-Provence, Jaap Bakema and André Wogenscky made their way into the CIAM Council and the organisation of CIAM 10, entitled The Habitat: problem of inter-relationships. CIAM's first proposals, statements and resolutions, was entrusted to Team 10 - Bakema, Georges Can dilis, Peter Smithson and Rolf Gutmann. Although they were supervised by the leadership, their appointment gradually launched a "takeover" and reorganisation of CIAM. This was done with Le Corbusier's support as he excluded himself from the leadership and directly supported Team 10 in his public address to CIAM 10 's participants. His letter was addressed to the pioneers of modern movement and to a new generation yet to come - the so-called "réalisateurs" - who would continue the mission of their predecessor and secure the future of CIAM. ${ }^{153}$

151 In CIAM manner, Team 10 produced its first official document - the Doorn Manifest - in early 1954.

152 Smithson, Team 10, 9-10.

153 The generation born in the 1900s was not neglected; they were also included in the group of founders. Le Corbusier was
Appointed in Dubrovnik and headed by Jap Bakema, the commission for reorganisation of CIAM was dysfunctional. Peter Smithson, one of its prominen members, openly advocated for CIAM's dissolution. Negotiations between the commission on one side and Sigfried Giedion, Walter Gropius and Jose Luis Ser did not produce any results. After a threeyear long search for a model of CIAM's reorganisation, the young abolished a national groups and in Otterlo in 1959 re-established a flexible network of free equitable and accountable individuals committed to the ideas of new architecture in the making. The gathering in Otter lo marked the end of CIAM and, officially, the end of a significant part of the history of architecture of the $20^{\text {th }}$ century.

\section{CONCLUSION}

Due to the circumstances of its establish ment, specific model of organisation and its internal dynamics, CIAM represents a paradigmatic example of an international socia network that defined a modernist canon in architecture and urbanism. Given the impact of the leading figures, Le Corbusier in particular, this network was highly centralised (egocentric), with a hierarchical model of decision-making. It was precisely this feature of the network that produced repeated ep isodes of resistance, based on generational and ideological confrontations. By analysing personal contacts and various types of links within the ideologically and generationally close group of architects, this paper aimed at following the trajectory of the left-oriented clique of CIAM and detecting the moments of discursive ruptures that called

the meeting with Team 10 in November 1954 (Message of Le Corbusier to the $\mathrm{X}$ Congres CIAM at Dubrovnik, in: CIAM 10 Dubrovnik 1956 (Zurich: gta ETH, 42-X-115A) 
into question the views of the CIAM leadership. Since the left-oriented clique in general terms presents part of the official historiography of CIAM, the purpose of this research was to analyse this case in depth, deploying the new methodology that we deem a fundamental contribution of this paper. The paper aimed to open up a new analytical field by relying on the relational database and network visualisations. Within this field, the history of architecture can be observed in terms of social networks (centrality, relations, social cliques), while the evolution of discourse can be put in relation to the social constellations within particular spatio-temporal coordinates. As the case of CIAM's left suggests, this approach to data visualisation focuses on the detection of alternative or parallel historical trajectories, "small histories" and peripheral phenomena that destabilise and question the positions of power of central historical narratives and predominant, mostly male figures who defined them. Specifically, some of the visualised social relations open a question of potential links between architects that were not in the focus of research up until now. At the same time, the proposed methodology points to a further research of the spatio-temporal trajectories of individuals, dynamics of $\mathrm{Cl}$ AM's national groups and the modality and medium of dissemination and transition of architectural and urban concepts in particular cultural settings and under specific historical circumstances. ${ }^{154}$ With the need to streamline the entry of a greater amount and more detailed data from primary and secondary sources in the database, this phase of research is yet to be reached.

154 The database developed within the ARTNET project allows for the entry of data on architectural projects, competitions, journals, publications, exhibitions and architectural and artistic groups. 
grebu 1911. od 1. svibnja do 1. lipnja. (Exhibition cat-

Kraševac, Irena. Ivan Meštrović i secesija. Beč München - Prag: 1900.-1910. Zagreb: Institut za povijest umjetnosti, and Fundacija Ivana Meštrovića, 2002.

Kraševac, Irena, and Željka Tonković. "Umjetničko umrežavanje putem izložaba u razdoblju rane moderne - sudjelovanje hrvatskih umjetnika na međunarodnim izložbama od 1891. do 1900. godine". Radovi Instituta za povijest umjetnosti, no. 40 (2016): 203-17.

Kraševac, Irena, and Petra Vugrinec, eds. Izazov moderne: Zagreb - Beč oko 1900, exhibition catalogue. Zagreb: Galerija Klovićevi dvori, 2017.

Kraševac, Irena, ed., 150 godina Hrvatskog društva likovnih umjetnika. Umjetnost $\mathrm{i}$ institucija. Zagreb: $\mathrm{Hr}-$ vatsko društvo likovnih umjetnika, Institut za povijest umjetnosti, 2018.

Kršnjavi, Izidor. "Druga izložba Društva hrvatskih umjetnika, I. Slovenski slikari," Narodne novine, December 31, 1900.

Krzysztofowicz-Kozakowska, Stefania, and Piotr Mizia. "Sztuka-Wiener Secession-Mánes. The central European Art Triangle," Artibus et Historiae, vol. 27, no. 53 (2006): 217-259.

Maruševski, Olga. Društvo umjetnosti 1868.-1879.-1941. Zagreb: Društvo povjesničara umjetnosti Hrvatske, 2004.

Milčinović, Andrija. “Umjetnička izložba," Savremenik, no. 8 (1911): 526-529.

Rollig, Stella, Irena Kraševac, and Petra Vugrinec, eds. The Challenge of Modernism: Vienna and Zagreb eds. The Challenge of Modernism: Vienna and Zagreb
around 1900, exhibition catalogue. Vienna: Belvedere,

Secessioni Europee. Monaco, Vienna, Praga, Roma, Palazzo Roverella, exhibition catalogue. Rovigo: Silvana Editoriale, 2017.

Wilhelmi, Christoph. Künstlergruppen in Deutschland, Österreich und der Schweiz seit 1900. Ein Handbuch, Stuttgart: Dr. Ernst Hauswedell \& Co., 1996.

Žerovc, Beti. Slovenski impresionisti. Ljubljana: Mladinska knjiga, 2013.

\section{ONLINE SOURCES}

Belvedere. "HAGENBUND. Ein europäisches Netzwerk der Moderne (1900 bis 1938)". Accessed January 5, 2019. http://tools.fas.at/hagenbund/exhibition.html
ArtHist Austria. "Exhibitions of Modern European Paintarthist.at/projektdetail/exhibitions-of-modern-eur pean-painting-1905-15.html

DALIBOR PRANČEVIĆ

Between Art Nouveau and the Avant-Garde: The Personal (Ego) Network of Ivan Meštrović and the Map of Critical Reception of His Work during the 1910s pp. 38-62

"Rus o Meštroviću". Srbobran April 4, 1911.

"Ruski glas o Meštroviću". Narodni list September 9, 1911.

"Ruski sud o Meštroviću". Brankovo kolo October 13, 1911.

Bulimbašić, Sandi. Društvo hrvatskih umjetnika "Medulić (1908.-1919.). Zagreb: Društvo povjesničara umjetnosti Hrvatske, 2016.

Clegg, Elizabeth. "Meštrović, England and the Great War." The Burlington Magazine, no. 144, (December 2002) 740-751.

Ivančić, Jasna, and Sanja Kreković-Štefanović, eds. Građa za bibliografiju Ivana Meštrovića od 1899. do 1993. Zagreb: Fundacija Ivana Meštrovića, Nacionalna i sveučilišna biblioteka, 1993.

Kečkemet, Duško. Život Ivana Meštrovića (1883.-1962. 2002.), Vol. I and Vol. II. Zagreb: Školska knjiga, 2009.

Kečkemet, Duško. Ivan Meštrović: Bibliografija 1899-2002. Split: Filozofski fakultet u Splitu, Duško Kečkemet, 2017. knjiga je u tisku.

Kraševac, Irena. Ivan Meštrović i secesija. Beč - München - Prag: 1900.-1910. Zagreb: Institut za povijest umjetnosti, and Fundacija Ivana Meštrovića, 2002.

Machiedo Mladinić, Norka. "Prilog proučavanju djelovanja Ivana Meštrovića u Jugoslavenskom odboru." Časopis za suvremenu povijest, vol. 39, no. 1 (June 2007): 133-156.

Meštrović, Ivan. Uspomene na političke ljude i događaje. Zagreb: Matica hrvatska, 1969.

Milačić, Karmen. Talijanska pisma Ivanu Meštroviću 1911 1921. Zagreb: Globus, 1987.

Prančević, Dalibor. "Odjek Ivana Meštrovića u Velikoj Britaniji nakon izložbe u Victoria \& Albert Museumu". In Zbornik II. kongresa hrvatskih povjesničara umjetnosti, Z5 403 . Zagreb: Institut za povjest umjenc
Prančević, Dalibor. "Sculpture by Ivan Meštrović at the Grafton Galleries in 1917: critical and social contexts." Sculpture Journal, vol. 25, no. 2 (2016): 177-192.

Prančević, Dalibor. Ivan Meštrović i kultura modernizma: ekspresionizam i Art déco. Split: Filozofski fakultet u Splitu, Muzeji Ivana Meštrovića, 2017.

Scott, John. Social Network Analysis: A Handbook. London: Sage Publications, 2000.

Vujanović, Barbara. "Doticaji umjetnika: Auguste Rodin i Ivan Meštrović". In Rodin u Meštrovićevu Zagrebu, edited by Jasminka Poklečki Stošić and Barbara Vujanović, 60-84. Zagreb: Umjetnički paviljon, Muzeji Ivana Meštrovića, 2015

\section{ARCHIVAL SOURCES}

Atelier Meštrović Archives, Letters collection, Zagreb.

University of Notre Dame Archives, Notre Dame, Indian 46556, Ivan Meštrović Papers, 1924- 1962.

\section{ONLINE SOURCES}

Bentkowska-Kafel, Ana. "Debating Digital Art History. International Journal for Digital Art History, no. 1 (2015) 50-64. https://doi.org/10.11588/dah.2015.1.21634b

TAMARA BJAŽIĆ KLARIN, NIKOLA BOJIĆ

CIAM Network Visualisation - Detecting Ideological Ruptures in the CIAM Discourse pp. 64-82

Anon., "Architecture et urbanisme en U.R.S.S." L'Architecture d'Aujourd'hui, no. 8 (1932): 49-96.

Bjažić Klarin, Tamara. Ernest Weissmann: društveno angažirana arhitektura, 1926 - 1939/Ernest Weissman Socially Engaged Architecture, 1926-1939. Zagreb: Hrvatska akademija znanosti i umjetnosti, Hrvatski muze arhitekture, 2015.

Bjažić Klarin, Tamara. "CIAM Networking - Internationa Congress of Modern Architecture and Croatian arch tects in the 1950s." Život umjetnosti, no. १९ (2016), 40-57. tectsin the 1950." Zivot umje science?" Papers of the Regional Science Association science?" Papers
no. 1 (1970): 6-21.

Huber, Benedikt. Die Stadt des Neuen Bauens. Projekte und Theorien von Hans Schmidt. Zürich: gta ETH, 1993.

Mumford, Eric. The CIAM discourse on urbanism, 1928 1960. Cambridge, Mass.: MIT Press, 2000.

Risselada, Max, and Dirk van den Heuvel, eds. Team 
Somer, Kees. The Functional City. The CIAM and Cornelis van Eesteren, 1928-1960. Rotterdam: nai010 publishers, 2007

Van Es, Evelin, et al., eds. Atlas of Functional City. CIAM 4 and Comparative Urban Analysis. Zürich, Bussum: gta Verlag \& Uitgeverij THOTH, 2014.

Wakeman, Rosemary. "Rethinking postwar planning history." Planning Perspectives, no. 2 (2014): 153-163.

Weissmann, Ernest. "We had another version of the charter." Arhitektura, no. 189-195 (198-1985): 32-37.

\section{ARCHIVAL SOURCES}

Bauhaus Archive, Gropius-Nachlass Collection, 12/505, Gropius, Walter, Letter to Sigfried Giedion, February 14, 1935.

gta ETH, 42-AR-14-130/131, Aspects of Program for CIAM $X$ at Dubrovnik to be given final form at Padova, Aug. 2/3. 1956.

gta ETH, 42-AR-1-1/21, CIAM 6 documents. Bridgwater, 1947

gta ETH, 42-JT-4-125/211, 7 CIAM Bergamo 1949. Document.

gta, ETH JT-6-1/139, CIAM 8. 1951 Report of Hoddesdon Conference.

gta ETH, 42-X-115A, CIAM 10 Dubrovnik 1956.

gta ETH, 42-AR-X-4, Les documents de Sigtuna 1952

gta ETH, 42-JT-12-317/353, Projet d'assistance techniques des Nations Unies.

gta ETH, 42-K-1930-W, Weissmann, Ernest, Letter to Sigfried Giedion, November 19, 1930.

Hrvatska akademija znanosti i umjetnosti, Hrvats muzej arhitekture, Vladimir Antolić Personal Archive, Radna grupa Zagreb, The first draft of the alternative version of the Athens Charter, August 10, 1933.

\section{ure to Institutional. Mainstream}

Culture. An Example of Network Analysis

Amaral, Aracy, ed. Projeto construtivo brasileiro na arte: 1950-1962. Rio de Janeiro: MAM, 1977.

Argan, Giulio Carlo. L'arte Moderna 1770-1970. Firenza: Sansoni, 1971.

Arte y cibernética: San Francisco, Londres, Buenos Aires. Exhibition catalogue. Centro de arte y Comunicación (CAYC): Buenos Aires, 1971

Azimuth 1 (3 September 1959), Milano, EPI editorials periodicals italiani.

Azimuth 2 (1 January 1960), Milano, EPI editorials periodicals italiani.

Bagley, Benjamin. "Loving Someone in Particular." Ethics 25/ 2 (January 2015): 477-507.

Berzano, Luigi, and Carlo Genova, Lifestyles and Subcultures: History and a New Perspective. London: Routledge, 2015.

Burnham, Jack. Beyond Modern Sculpture: The Effects of Science and Technology on the Sculpture of This Century. New York: George Braziller, 1968.

Cainaello, Tiziana, and Mattijs Visser, eds. The Artist as Curator. Collaborative initiatives in the international ZERO movemnet1957-1967. Gent: MER. Paper Kunsthalle, 2015

Calvert, Gemma, Charles Spence, and Barry E. Stein, ds. The Handbook of Multisensory Processes. Cambridge Mass.: The MIT Press, 2004.

Cempellin, Lisa. The Ideas, Identity and Art of Daniel Spoerri. Contingencies and Encounters of an 'Artistic Animator'. Wellington: Vernon Press, 2017.

Computer und visuelle Forschung. Zagreb 1961-1973. Exhibition catalogue. Karlsruhe: ZKM, 2007.

Corà, Bruno. Tinguely and Munari. Exhibition catalogue. Tinguely e Munari - I Opere in azione, CAMeC. La Spezia: Centro Arte Moderna e Contemporanea, 2004.

D’Assunção Barros, José. "Mário Pedrosa e a Crítica de Arte no Brasil." Ars - Revista do Programa de Pós-Graduação em Artes Visuais (ECA) do Escol en da Universidade de São Paulo 6/11 (January-July 2008): 40-61.
1918-1991, edited by Dubravka Djurić and Miško Šuvaković. Cambridge Mass.: The MIT Press, 2003.

Denegri, Jerko. Constructive Approach Art: Exat 51 and New Tendencies. Zagreb: Horetzky, 2004.

Denegri, Jerko. "Die Bedingungen und Umstände, die den ersten beiden Ausstellungen der Nove Tendencije in Zagreb (1961-1963) vorausgingen“" In bit international. [Nove] tendencije - Computer und visuelle Forschung. [Nove] tendencie - Computer und visuelle Forschung. ZKM, 2007.

Die Neuen Tendenzen: eine europäische Künstlerbe wegung 1961-1973. Exhibition catalogue. Ingolstadt, Düren: Museum für Konkrete Kunst, Ingolstadt (29 September 2006-7 January 2007); Leopold-Hoesch-Museum, Düren (28 January-25 March 2007).

Dhoest, Alexander, Steven Malliet, Jacques Haers, and Barbara Segaert, eds. The Borders of Subculture: Resistance and Mainstream. London: Routledge, 2015.

Dossin, Catherine. "To Drip or to Pop? The Europea Triumph of American Art." Art!@s Bulletin, Vol. 3, No.1 (Spring 2014), 79-103.

Drew Egbert, Donald. Social Radicalism and the Arts - Western Europe. A Cultural History from the French Revolution to 1968. New York: Alfred A. Knopf, 1970.

Elger, Dietmar, and Elizabeth M Solaro. Gerhard Richter A Life in Painting. University of Chicago Press, 2010.

Fritz, Darko. "New Tendencies / Nove tendencije." Oris 10/54 (2008): 176-191.

Galimberti, Jacopo. Individuals against Individualism Art Collectives in Western Europe (1956-1969). Liverpool Liverpool University Press, 2017.

García, Maria Amália. "Ações e contatos regionai da arte concreta. Intervenções de Max Bill em São Paulo em 1951." Revista Universidade de São Paulo 79 (September-November 2008): 196-204.

Gelder, Ken. Subcultures: Cultural Histories and Social Practice. London: Routledge, 2007

Granzotto, Govanni. "Arte programmata e cinetica: origini, successo, declino, rinascita." In Arte programmata e cinetica Italiana. Exhibition catalogue (11 October - 8 December 2013. MACBA) Buenos Aires: Museo de Arte Contemporáneo de Buenos Aires (MACBA), 2013.
Von Graevenitz, Antje. “Gerhard von Graevenitz as Curator, Gallerist, Editor, and Lecture Organizer." In The Artist as Curator. Collaborative initiatives in the interAtional ZERO Movement 1957-1967, edited by Tizian Cainaello and Mattijs Visser, 290-291. Gent: MER. Paper Kunsthalle, 2015.

Hoffmann, Tobias, ed. Die neuen Tendenzen: Eine europäische Künstlerbewegung 1961-1973. Heidelberg: Edition Braus, 2006.

Huizing, Colin, and Tijs Visser, eds. nul $=0$. The Dutch Nul Group alogue. Schiedam, Amsterdam: Stedelijk Museum \& NA Publisher, 2011.

Jakšić, Jasna, and Ivana Kancir, eds. Nowa sztuka dla nowego społeczeństwa / New Art for New Society. Wrocław: Muzeum Współczesne Wrocław, 2015.

Kadushin, Charles. Understanding Social Networks Theories, Concepts and Findings. New York: Oxford University Press, 2012.

Klütsch, Christoph. "The Summer 1968 in London and Zagreb: Starting or End Point for Computer art?" I Proceedings of the 5th Conference on Creativity \& Cognition. New York: ACM, 2005: 109-117.

Klütsch, Christoph. Computergrafik: Ästhetische Experimente zwischen zwei Kulturen. Die Anfänge der Computerkunst in den 1960er Jahren. Vienna/New York Springer, 2007.

Kolešnik, Ljiljana. "Zagreb as the Location of the New Tendencies International Art Movement (1961-73)". In Art beyond Borders: Artistic Exchange in Communist Europe (1945-1989), edited by Jérôme Bazin, Pascal Dubourg Glatigny and Piotr Piotrowski, 311-321. Budapest: Central European University Press, 2016.

Kolešnik, Ljiljana, Nikola Bojić, and Artur Šilić. "Reconstruction of Almir Mavignier's Personal Network and its Relation to the First New Tendencies Exhibition. The example of the Application of Network Analysis and Network Visualization in Art History." Život umjetnosti, no. 99 (2016): 58-79.

Konkrete Kunst - 50 Jahre Entwicklung. Exhibition catalogue. Zürich: Kunsthalle, 1960.

Krampen, Martin, and Günter Hörmann, eds. Die Hochschule für Gestaltung Ulm / The Ulm School of Design. Berlin: Ernst \& Sohn, 2003.

Kuhn, Anette. Zero: eine Avantgarde der sechziger Jahre. Frankfurt am Main \& Berlin: Propyläen-Verl., 1991. 